\title{
Lipoma en lengua: aportación de un caso
}

\section{Lingual Lipoma: contribution of one case}

\section{J. Orozco Ariza1 , M. Fonseca Ricaurte2, A. Díaz Caballero²}

Resumen: Los tumores de la cavidad oral y estructuras adyacentes son parte importante de la odonto-estomatología por el papel que el profesional de la cavidad bucal juega en el diagnóstico y tratamiento de estas lesiones.

Los lipomas son neoplasias benignas de células adiposas, sumamente raras en la cavidad oral. La mucosa bucal, lengua y piso de boca son algunos de los sitios más comunes. La presentación clínica típica es la de una lesión tumoral asintomática, submucosa de color amarillo. La eliminación quirúrgica es el tratamiento de elección, rara vez se observan recurrencia.

Se presenta caso clínico de lipoma en lengua en paciente femenino de 23 años de edad, que compromete línea media de cara dorsal de lengua a nivel de tercio medio y posterior.

Palabras clave: Lipoma; Células adiposas; Neoplasia benigna; Lipoma de lengua.

Recibido: 2.2.2009

Aceptado: 11.05.2009
Abstract: Tumors in the oral cavity and the adjacent structures are an important part of the stomatology because of the role that the oral cavity professional plays in the diagnosis and treatment of these lesions.

Lipomas are benign neoplasias made up of adipose cells, extremely rare in the oral cavity. The buccal mucosa, tongue and floor of the mouth are some of the most common sites for these lipomas. The typical clinical case includes a painless tumor and a yellow sub mucosa. The chosen treatment is surgical removal. Recurrences are very rare.

We present the clinical case of a 23 year old female with lingual lipoma that endangers the mid line of the dorsal tongue at the middle third.

Key words: Lipoma; Adipose cells; Benign neoplasia; Lingual lipoma.

\footnotetext{
1 Odontólogo Universidad Metropolitana de Barranquilla. Especialista en Estomatología y Cirugía Oral Universidad de Cartagena. Profesor Asociado Facultad de Odontología Universidad de Cartagena. Colombia

2 Odontólogo Universidad De Cartagena. Especialista en Periodoncia Universidad Javeriana, Magíster en Educación Universidad del Norte, Profesor Titular Facultad de Odontología Universidad de Cartagena. Colombia
}

\section{Correspondencia:}

Antonio Díaz Caballero

Universidad De Cartagena, Facultad de Odontología

Departamento de Investigaciones.

Campus de la Salud Barrio Zaragocilla. Cartagena, Colombia

Email: antoniodiazc@yahoo.com 


\section{Introducción}

Los primeros reportes de lipoma en cavidad oral fueron descritos por MacGregor y D.P. Dyson en 1966. Posteriormente fueron publicados nuevos casos de significancia clínica de lipoma en la región oral y maxilofacial en 1973 por Greer y Richardson. ${ }^{1}$

La presentación clínica típica es la de una lesión tumoral de crecimiento lento y asintomática, de consistencia blanda, que se manifiesta al causar desplazamiento y compresión en las estructuras adyacentes cuando alcanza un gran tamaño. ${ }^{2}$ Se presenta de forma aislada o lobulada, con un tamaño que varia de 1 a $2 \mathrm{~cm}$, de superficie lisa bien delimitada, adherida por una base sésil o pediculada y de color amarillo. El epitelio que la cubre se encuentra intacto $y$ los vasos sanguíneos suelen ser evidentes sobre el tumor. ${ }^{3}$

Los lipomas de cavidad oral pueden aparecer en diversos sitios anatómicos tales como glándulas salivares mayores, mucosa bucal, labios, lengua, paladar, vestíbulo y suelo de boca. En numerosos artículos de casos se han descrito lipomas y variantes del mismo en diversas localizaciones, demostrando que el sitio más predominante para su aparición es la lengua. ${ }^{1}$

A pesar que su etiología es desconocida, se sugieren factores como traumatismo, infección, irritación crónica y alteraciones hormonales como posibles causantes de su aparición. ${ }^{2}$

Microscópicamente el tumor consiste en células adiposas maduras incluidas dentro de un tejido alveolar fino y rodeado por una cápsula fibrosa. Hay un estroma fibroso que divide la grasa en lóbulos y contiene pequeños vasos sanguíneos. ${ }^{4}$

Desde el punto de vista histológico, los lipomas están subdivididos en un número de entidades: Lipoma simple, Angiolipoma, Fibrolipoma, Lipoma de células estrelladas o pleomorfico, Miolipoma, Mielolipoma, Lipoma condroide, Lipoma mixoide, Lipoblastomatosis, Lipomatosis, Hibernoma y Lipoma atípico. ${ }^{1}$

En el diagnostico diferencial pueden incluirse otras lesiones benignas de tejido conectivo, por ejemplo el tumor de células granulares, neurofibroma, fibroma traumático y malformaciones de las glándulas salivares (mucoceles y tumor mixto). ${ }^{5}$

La eliminación quirúrgica de la lesión es el tratamiento de elección, rara vez se observan recurrencias y si estas existen se asocian a una extirpación incompleta de la neoplasia. ${ }^{6}$

\section{Presentación del Caso Clínico}

Paciente de 23 años de edad, de género femenino, que acude a consulta, a la unidad de estomatología y cirugía oral de la facultad de odontología de la Universidad de Cartagena por presentar tumor en línea media, entre tercio medio y posterior de cara dorsal de lengua. Se confirma la presencia de la tumoración desde el nacimiento, la cual fue evolucionando y aumentando de tamaño. Al examen físico extraoral se observa una paciente colaboradora, con buen estado nutricional, signos vitales y apariencia física general dentro de lo normal. Niega antecedentes familiares y personales de importancia con relación al motivo de consulta.

Al examen intraoral se evidencia tumor en línea media entre tercio medio y posterior de cara dorsal de lengua de $2 \times 3 \mathrm{~cm}$, de base

\section{Introduction}

The first reports of lipoma in the oral cavity were described by Mac Gregor and D.P. Dyson in 1966. In 1973, new clinically significant cases were published in the oral and maxillofacial field by Greer and Richardson. ${ }^{1}$ Typical clinical appearance is a painless slow growing tumor that is soft and starts to cause displacement and compression of the adjacent structures as it grows larger in size. ${ }^{2}$ It appears isolated or obulated between 1 and $2 \mathrm{~cm}$ in size, has a well defined smooth surface, is attached by a sessile or pediculed base and is yellow in color. The epithelium that covers it is in tact and blood vessels are usually easily seen over the tumor. ${ }^{3}$

Oral cavity lipomas can appear in various anatomic sites including: major salivary glands, oral mucosa, lips, tongue, palate, and mouth floor. In many of the cases reported lipomas and variants have been described in diverse locations while the most common location is the tongue. ${ }^{1}$

Although its etiology is unknown possible causes include trauma, infection, chronic irritation and hormone alterations. ${ }^{2}$

Microscopically the tumor consists of mature adipose cells that are found within the fine aleveor tissue and surrounding a fibrous capsule. There is a fibrous stroma that divides the lobe fat and contains small blood vessels. ${ }^{4}$

From a histological point of view, the lipomas are subdivided by a number of entities: Simple Lipoma, Angiolipoma, Fibrolipoma, starred or Pleomorphic cell Lipoma, Myolipoma, Mielolipoma, Chondroid Lipoma, Myoid Lipoma, Lipoblastomatosis, Lipomatosis, Hybernoma and Atypical Lipoma.

The differential diagnosis can include other benign lesions of connective tissue, for example a granulated cell tumor, neurofibroma, trauma fibroma and salivary gland deformities (mucocells and mixed tumor). 5 Surgical elimination of the lesion is the treatment of choice, recurrences are rarely occur and if they do occur they are associated with incomplete removal of the neoplasia. ${ }^{6}$

\section{Report of the Clinical Case}

23 year-old female patient goes to the stomatology and oral surgery unit of the Faculty of Odontology at the University of Cartagena because of a lingual lipoma that endangers the mid line of the dorsal tongue at the middle third. The patient's mother reports that the tumor has been present since birth and since then it has increased in size. During the extra oral physical examination the patient is cooperative and appears to be in good nutritional health, has normal vital signs and is in good general physical condition. The patient reports no prior personal or family histories related to this consult.

The intraoral exam shows evidence of a tumor on the midline of the dorsal tongue at the middle third. It is $2 \times 3 \mathrm{~cm}$ 
pediculada, consistencia cauchosa, asintomática, la mucosa que lo recubre transluce color amarillento y presenta vasos sanguíneos superficiales. Con la impresión clínica de lipoma de lengua y diagnóstico diferencial con tiroides lingual, se realizan exámenes de laboratorio (gammagrafía con yodo 99) para determinar la posición y función de la glándula tiroides, con lo que se descarta la presencia de tejido tiroideo ectópico (Fig. 1).

Se realiza biopsia excisional bajo anestesia local peritumoral e incisión en la base del pediculo en forma de cuña, se sutura con seda 4-0 (Fig. 2). El procedimiento fue bien tolerado y sin complicaciones, se prescribe amoxicilina 500 mg una capsula cada 8 horas por 7 días y acetaminofen 500 mg tabletas cada 6 horas por 5 días. Se remite la muestra a estudio histopatológico confirmándose el diagnóstico de lipoma. Se realizan controles post quirúrgicos a los $8,15,30$ días, a los 3, 6, 12 meses, 2, 3, 5 años sin evidencia de recidiva.

\section{Discusión}

Los Lipomas son tumores benignos de tejido adiposo maduro, raros en cavidad oral, 7 pero debe ser considerado dentro de los posibles diagnósticos diferenciales que se planteen teniendo en cuenta las características clínicas descritas anteriormente; además es importante tener en cuenta el diagnostico diferencial de tiroides lingual cuando el lipo-

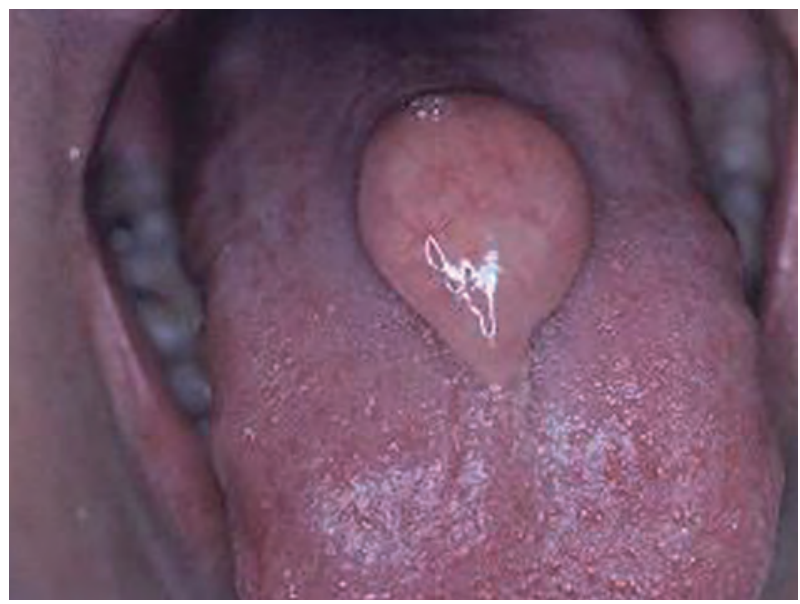

Figura 1. Aspecto clínico de la lesión, de consistencia elástica, base pediculada. Obsérvese la mucosa que lo recubre de color amarillento y presenta vasos sanguíneos superficiales.

Figure 1. Clinical aspect of lesion, elastic consistency, pedicled base. Observe the mucosa that covers it, its yellow color and the blood vessels on the surface.

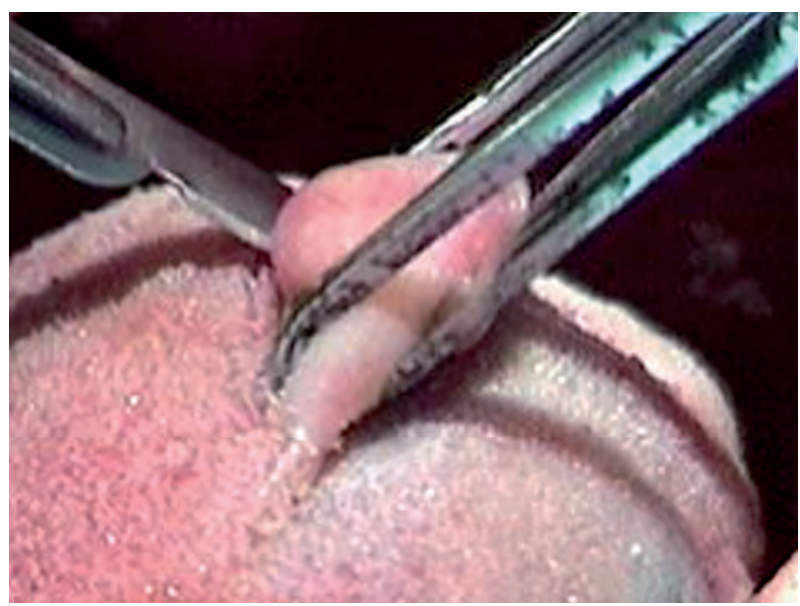

Figura 2. Cirugía para extirpación quirúrgica de la lesión. Figure 2. Surgery to remove the lesion. in size with a pediculed base, a rubbery consistency, painless, it is covered by a yellow translucent mucosa and there are blood vessels on the surface. The clinical impression is lingual lipoma and the differential diagnostic is lingual thyroids. We perform laboratory tests (scintigraph with iodine 99) to determine the position and purpose of the thyroid glands which reveal the presence of ectopic thyroid tissue (Fig. 1).

An excision biopsy is performed under local peritumor anesthetic and an incision is made at the base of the pedicle in the shape of a cradle, it is stitched with 4-0 thread (Fig. 2). The procedure was well tolerated and there were no complications. Amoxicillin $500 \mathrm{mg}$ was prescribed, one capsule every 8 hours for 7 days and acetaminophen $500 \mathrm{mg}$ tablets every six hours for 5 days. The sample was sent for a histological study which confirmed the lipoma diagnosis. Post surgery follow-up took place 8, 15, and 30 days after surgery as well as 3, 6 and 12 months and 2, 3, and 5 years after surgery without any report of relapse. ma presenta esta localización.

Los lipomas comprenden entre el 2,2\% y el $4,4 \%$ de todos los tumores benignos de cabeza y cuello. ${ }^{1,8}$ Los lipomas de lengua ocurren con mayor frecuencia en individuos de 30 a 40 años de edad o mayores y no son comunes en la edad infantil. ${ }^{9}$

Los lipomas solitarios, como el encontrado en el presente caso, son considerados como verdaderas neoplasias y no como defectos del desarrollo. El lipoma congénito de lengua es reportado en varios estudios pero son muy raros y se sugiere en algunos cierta predisposición familiar, ${ }^{10}$ en el presente caso la paciente presentó la tumoración desde el nacimiento y fue aumentando de tamaño al transcurrir el tiempo sin encontrarse antecedentes en la familia de esta patología.

El tratamiento del lipoma es quirúrgico y el pronóstico es bastante bueno, sin embargo se informa recidiva en pacientes menores de 18 años y desarrollo de liposarcoma después de muchas recurrencias, ${ }^{11-13}$ por lo tanto es necesaria la excisión amplia con un margen de tejido sano para prevenir la recurrencia local.

\section{Discussion}

Lipoma are benign tumors made up of mature adipose tissue, rarely found in the oral cavity but should be considered among possible differential diagnosis taking into account the clinical characteristics we described earlier. It is also important to take into account the differential diagnosis of lingual thyroids when lipoma is found in his area.

Lipomas make up 2.2\%-4.4\% of all head and neck benign tumors. ${ }^{1,8}$ Lingual lipomas mainly occur in individuals aged $30-40$ or in older people, they are not common in pediatric patients. ${ }^{9}$

Solitary lipomas, like the one we found in this case, are considered true neoplasias not developmental defects. Congenital lingual lipoma is reported in multiple studies but they 


\section{Bibliografía}

1. Furlong MA, Fanburg-Smith JC, Childers EL. Lipoma of the oral and maxillofacial region: Site and subclassification of 125 cases. Oral Surg Oral Med Oral Pathol Oral Radiol Endod 2004;98:441-50.

2. Del Castillo JL, Cebrián JL, Gómez E. Chronic lingual ulceration caused by lipoma of the oral cavity. Case report. Med Oral 2004;9:166-7,163-6.

3. Trandafir D, Gog_Iniceanu D, Trandafir V, C_runtu ID. Lipomas of the oral cavity-a retrospective study. Rev Med Chir Soc Med Nat lasi 2007;111:754-8.

4. Fregnani ER, Pires FR, Falzoni R, Lopes MA, Vargas PA. Lipomas of the oral cavity: clinical findings, histological classification and proliferative activity of 46 cases. Int J Oral Maxillofac Surg 2003;32:49-53.

5. Regezi JA, Sciubba JJ. Patología Bucal. Tercera edición. México: McGraw-Hill Interamericana 2000.

6. Mighell AJ. Lipoma--an unusual alveolar swelling. Br Dent / 1994;176:225-6.

7. Ghandour K, Issa M. Lipoma of the floor of the mouth. Oral Surg Oral Med Oral Pathol 1992 Jan;73:59-60.

8. Lombardi T, Odell EW. Spindle cell lipoma of the oral cavity: report of a case. J Oral Pathol Med 1994;23:237-9.

9. Fornage BD, Tassin GB. Sonographic appearance of superficial soft tissue lipomas. J Clin Ultrasound 1991;19:215-20.

10. Ghossaini SN, Hadi U, Tawil A. Oral-facial-digital syndrome type II variant associated with congenital tongue lipoma. Oral Surg Oral Med Oral Pathol Oral Radiol Endod 2002;94:324-7.

11. Zhong LP, Zhao SF, Chen GF, Ping FY. Ultrasonographic appearance of lipoma in the oral and maxillofacial region. Oral Surg Oral Med Oral Pathol Oral Radiol Endod 2004;98:738-40.

12. Moore PL, Goede A, Phillips DE, Carr R. Atypical lipoma of the tongue. J Laryngol Otol 2001;115:859-61.

13. Adoga AA, Nimkur TL, Manasseh AN, Echejoh GO. Buccal soft tissue lipoma in an adult Nigerian: a case report and literature review. I Med Case Reports 2008;2:382. are very rare and sometimes occur in those with a family history. ${ }^{10}$ In the current case the patient has had the tumor since birth and it has been increasing in size over time, the patient has no family history of this pathology.

Treatment for lipoma is surgery and the prognostic is pretty good. However, relapse is reported in patients younger than 18 years old. These patients also report development of liposarcoma after many relapses. As a result, it is necessary to remove a large area of tissue surrounding the lipoma in order to prevent recurrence. 